\title{
Intellectual capital disclosure determinants and its effects on the market capitalization: evidence from Indonesian listed companies
}

\author{
Angga Arifiawan Sudibyo, ${ }^{1, *}$, and $B$. Basuki $^{2}$ \\ Faculty of Economics and Business, Universitas Airlangga, Surabaya, Indonesia
}

\begin{abstract}
Currently, intellectual capital (IC) is the main source of company's competitive advantage. The role of IC has become one of the main factors of company's value creation process. Since companies rely more on their intangibles (including IC), management must provide an appropriate annual report in which discloses information regarding IC in order to give better information to the related parties. The aim of this study is to examine variables that expected to have a significant influence to the level of intellectual capital disclosure (ICD) practices in Indonesian listed companies' annual reports. A content analysis method is used to examine the ICD level, based on the framework developed by [1]. The IC information was collected from 135 Indonesian LQ45 listed companies, which derived from their annual reports from the year 2012 to 2014. Sample companies are classified into two groups of industries: high- and low profile industries in order to analyze differences in IC reporting practices between the two groups. The empirical results proved that company size, industry type and market capitalization are significantly associated with the ICD, while the influence of company profitability on the level of ICD is not significant. Furthermore, it is revealed that there is no significant difference in the intellectual capital disclosure practices between companies in high- and lowprofile industries.
\end{abstract}

Keywords: Intellectual capital disclosure; Content analysis; Annual report; Industry type; LQ45; Indonesia Stock Exchange; Independent t-test; Market Capitalization, ROA

\section{Background}

Recently, new economies are shifting towards a knowledge-based economy or knowledge economy (KE) in which companies' competitiveness and sustainability are increasingly dependent of knowledge based resource. The dramatic shift from material sources to knowledge, from hardware to software is actually experiencing by companies across the world. Their key economic resources are no longer natural resource or physical capital, but the knowledge itself [2]. The transition from manufacturing-based economies towards knowledge-based economy makes a continuous enhancement of IC importance in company's value creation process.

[3] found that the relevance of traditional financial accounting model is unable to represents the key factors of company's long term value (i.e., intangible assets). Companies with traditional financial accounting valuation method are based on balance sheet, income statement or statement of cash flow. Stakeholders have been dissatisfied with this traditional financial reporting made by companies and its capability to present users with sufficient information about company's ability to create wealth. [4] as one of the pioneers in intellectual capital studies are argued that reporting intellectual capital of companies' intangible assets is a substantial way of connecting the information gap that may exist between owners and managers.

There are numerous prior study related to IC and even they have taken similar variables, but the empirical results were varying and several studies have contradictory results. This condition is likely happened because until now there is still no

*Corresponding author: anggasudibyo@live.com 
regulation or standards of reporting of IC information on the annual reports. In case of Indonesia, the regulation regarding to components of Intellectual Capital is stated in [5]. However, the scope is very limited only for intellectual property that can be included in traditional financial statement. The list of IC items that should be reported in the company's annual report until now is still not regulated yet.

This study concentrates on empirical study on the firms' characteristics (company size, industry and profitability) that becomes the determinants of ICD. It is aimed to also find empirical evidence on the influences of Intellectual Capital of company that represented in their annual report to its market capitalization during the year 2012 until 2014. Companies listed in LQ45 index selected as the sample in this study. LQ45 companies are known for their high market capitalization and transaction value, and also have a good prospect of growth. Thus, those companies are expected to be more active in disclosing their IC. These companies come from various industries so then it is expected to be able in representing two types of industries (high- and low-profile) that become one of the variables in this study. This study also hopes to be able in comparing the level of intellectual capital disclosure between companies in high-profile and low-profile industries.

\section{Literature review and hypotheses development}

Under the stakeholder theory, a company should consider that stakeholders have a powerful competency to influence management in managing the resources owned by the company. The greater power of stakeholders, the greater company's effort in creating value will be. By appropriately managing the resources, the company will be able to create more value and enhance the financial performance. A company's strategic information including IC information should be communicated to the stakeholders in order to meet their needs. Therefore, as the company disclose their IC information, it is expected to raise the confidence of stakeholders regarding to the company and reduce the risk and uncertainty faced by investors.

A company's resources consist of all assets, both tangible and intangible, capabilities, organizational processes, human and nonhuman identified and controlled by the company, and that permit it to consider and apply value-enhancing strategies [6]. Based on Resource-based View (RBV) Theory, a company will have a competitive advantage when it is able in implementing a value creating strategy, not by simultaneously being implemented by any current or potential competitors. [7] explained about difference strategies (defender and prospector) can be implemented by company to reach its competitive advantage. Knowledge based resource is mainly derived from the RBV ideas. Knowledge resource within a company will allow company to compete either by being a defender or prospector. Intellectual capital, according to RBV point of view, is considered as an important source of competitive advantage because IC items are mostly able to fulfil the attributes of good resource. Thus, it is expected to make a competitive advantage for the company.

Moreover, the basic ideas of signalling theory stated in [8] signalling is a reaction to information asymmetry, it was also used in many accounting studies to explain voluntary disclosure practices of accounting information [9]. [8] proposed that between two parties could get asymmetric information problem if one party send a signal that would reveal some relevant information to the other party. Thus, that informed party will interpret that given signal and adjust the purchasing behaviour. Information of IC in the annual report can be interpreted as a signal. Companies should signal their IC to their stakeholder or to the capital market as "good news" in order to increase the share price or attract new investors.

\subsection{Intellectual Capital Disclosure}

Intellectual Capital is often divided into different components: human capital (HC), relational capital (RC), and structural capital (SC). HC includes knowledge, skills, and experience owned by the employees of the company. Structural capital (SC) refers to knowledge that attached to the structure and organization process, including corporate culture, share of knowledge, technology, and availability of information systems. Relational or Customer capital is a good relation (association network) owned by company to its stakeholders. The relation here refers to the supplier relations, customer loyalty, goodwill and a good relation with government and society in general. Petty and [10] argues that external capital defined as company's ability to identify the need of the market, so that a good relation may be build between company and external parties. It is argued that between these two IC components is dependent-independent each other. [10] stated that the creation of patent highly depends on the HC, but after it is completed, it considered as company's SC. Information on intellectual capital is important to stakeholders in their decision-making. The greater disclosure provide by a company might reduces the uncertainty be faced by investors and thus it will reduce company's cost of capital. Even though disclosing intellectual capital still voluntarily done by the company, but the number of companies that realized the importance of reporting non-financial information is increasing over years.

\subsection{Company Size}

Company sixe is reflected by the value of total assets stated in company's balance sheet. The greater amount of total assets, the larger the size of a company, and vice versa. The size of company may affect the company's operating capabilities that will affect the share returns of companies. Studies by [11], [12] and [13] found that size is a significant determinant for 
intellectual capital disclosure. [12] notes that large companies are basically have more value-driven activities and also larger companies being more visible and obtain more attention by the stakeholders, such as public and government.

H1: $\quad$ Company size has influences on the intellectual capital disclosure

\subsection{Industry Type}

Information disclosed by companies in particular industry which they consider as relevant, is might not always considered as relevant information for companies in another industry [14]. This study propose that type of industry is a key factor for intellectual capital disclosure recall that intellectual capital among companies in some industries are more important than companies in other industries. The sample is into two groups of industries which are high-profile and low-profile industry. High-profile industries as companies with high consumer visibility, political risk and strong competition among its competitors and whose economics activities more likely to modify their environment, more often discloses the environment impacts rather than other industries, while low-profile industries are the otherwise of high-profile industries. According to [15] companies classified into high-profile industries are mining, chemical, wood, automotive, aviation, agriculture, tobacco and cigarettes, food products and beverages, media and communications, energy (electricity), engineering, health and transport and tourism. Meanwhile, companies in low-profile industries include real estate industry, finance and banking, healthcare, consumer goods, retail and household products. The general expectation is that companies in high-profile industries will disclose more IC information than companies in low-profile industries. High profile companies are more likely to be reliant on intellectual capital and therefore high profile companies are likely to disclose more intellectual capital information under the annual reports.

H2.1 Industry types has influences on the intellectual capital disclosure

H2.2 There is a significant difference of the level of intellectual capital disclosure between high-profile and low-profile industries

\subsection{Profitability}

Companies with higher profitability are expected to disclose more information to the public in comparison to the companies with lower profitability. According to [6] resource-based view (RBV) theory, companies are able to generate value and will indicate a profitable growth if they follow those growth opportunities that will fit to their resources base. Higher profit companies are mainly attributed to their competitive advantage. Companies that have competitive advantages assumed that they have more financial resources so then they are able to disclose more.

H3 Company's profitability has influences on the intellectual capital disclosure

\subsection{Market Capitalization}

Market capitalization can be defined as the total worth of companies' securities in the capital market [16]. IC is a part of companies' capital and resources, in which contributes to the wealth creation process. Information regarding IC in annual reports helps to make capital markets more efficient by reducing the information asymmetry problems between management of company and its investors. Additionally, IC disclosure helps the capital market to provide a more accurate market capitalization of firms [17]. When stakeholders have better understanding about the company, they will belief in company's future capabilities in creating more profit, so then it might raise the company stock price (market capitalization increase).

Company's Market Capitalization is influenced by the disclosure of Intellectual Capital

\subsection{The differences of ICD between High Profile and Low Profile Industry}

This study divided the sample companies into two groups of industries which are high-profile and low-profile industry. Thus, from the study it is expected to be able in explaining any differences of the level of ICD between those two types of industries. The general expectation is that companies in high-profile industries will disclose more IC information than companies in low-profile industries. High profile companies are more likely to be reliant on intellectual capital and therefore high profile companies are likely to disclose more intellectual capital information under the annual reports. However, a study by [11] has been found that companies belonging to high-profile and low-profile industries disclose the same level of ICD under the annual reports.

H5 There is a significant difference of the level of intellectual capital disclosure between high-profile and low-profile industries

\section{Research methods}

\subsection{Sample Selection}


Data collected are obtained by using documentation technique which comprising the company's annual reports. A sample of Indonesian LQ45 companies was selected for content analysis of the annual reports from the three-year periods from 2012 until 2014. The reason behind the selection of LQ45 is due to it is the 45 most liquid and most heavily traded stocks in the Indonesia Stock Exchange (IDX). Additionally, it represents various industries in the stock market.

\subsection{Content analysis of annual report}

This study uses content analysis to collect empirical data about ICDs [18]. Content analysis has been argued as the most reasonable methodology for data collection. The ICD index used in this study replicates the index constructed to measure both the extent and quality of IC disclosures (Li et al., 2008). This index contains of 61 items that covered the three IC subcomponents of structural, relational, and human capital. 22 items are HC elements, 18 are SC, and the remaining 21 represent RC elements (see Table 3.1). IC related items appears on the annual report will be scored 1, if there is no disclosure will be scored 0 . Thus, the sum of all obtained scores represents company's ICD score. The level of disclosure for each company's annual report is then calculated by dividing the sum or total score of disclosure with the total number of items scored.

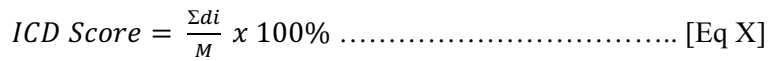

There are three independent variables: company size, industry type, profitability, and intellectual capital disclosure, while the dependent variables are intellectual capital disclosure and market capitalization.

Table 3.1: IC Framework

\begin{tabular}{|c|c|}
\hline \multicolumn{2}{|c|}{ Classification of intellectual capital, $\mathrm{Li}$ et al (2008) } \\
\hline Human Capital & Relational Capital \\
\hline Number of Employee & Customers \\
\hline Employee age & Market presence \\
\hline Employee Diversity & Customer relationships \\
\hline Employee Equality & Customer acquisition \\
\hline Employee Relationship & Customer retention \\
\hline Employee Education & CTE \\
\hline Skills/ know-how & Customer involvement \\
\hline Employee Competences & Company image \\
\hline Employee Knowledge & Company awards \\
\hline Employee Attitudes & Public relation \\
\hline Employee Commitments & Diffusion \& networking \\
\hline Employee Motivation & Brands \\
\hline Employee Productivity & Distribution channels \\
\hline Employee Training & Relationship with suppliers \\
\hline Vocational Qualifications & Business Collaboration \\
\hline Employee Developments & Business agreements \\
\hline Employee Flexibility & Favourite contract \\
\hline Entrepreneurial Spirit & Research collaboration \\
\hline Employee Capabilities & Marketing \\
\hline Employee Teamwork & Relationship with stakeholders \\
\hline Employee Community Involvement & Market leadershin \\
\hline \multicolumn{2}{|l|}{ Other Employee Features } \\
\hline \multicolumn{2}{|l|}{ Structural Capital } \\
\hline Intellectual Property & Technology \\
\hline Process & Financial dealings \\
\hline Management Philosophy & Customer support function \\
\hline Corporate Culture & Quality management \& improvement \\
\hline Organization Flexibility & Knowledge-based infrastructure \\
\hline Structure & Accreditations (certificate) \\
\hline Learning & Overall infrastructure/ capability \\
\hline Research \& Development & Networking \\
\hline Innovation & Distribution Network \\
\hline
\end{tabular}




\section{Results and discussions}

The results of multiple linear regression analysis show that variable SIZE and TYPE has significant influence towards the level of ICD, while company's profitability, denoted by ROA has no significant influences towards the level of ICD. The second model examines the level of IC owned by company presented by ICD on annual reports towards company's Market Capitalization (MCAP) proved that the relationship between these two variables is significant. Table below provides the result of independent sample t-test in regard to compare the level of ICD between Indonesian companies in high- and low-profile industries.

\begin{tabular}{|c|c|c|}
\hline \multicolumn{3}{|c|}{ Simple Regression Results (Model 2) } \\
\hline \multirow{2}{*}{ Independent Variables } & \multicolumn{2}{|c|}{ MCAP } \\
\hline & t-statistic & Sig. \\
\hline ICD & 5.082 & 0.001 \\
\hline \multicolumn{3}{|c|}{ Multiple Regression Results (Model 1) } \\
\hline \multirow[b]{2}{*}{ Independent Variables } & \multicolumn{2}{|c|}{ ICD } \\
\hline & t-statistic & Sig. \\
\hline SIZE & 3.639 & 0.001 \\
\hline TYPE & 1.868 & 0.064 \\
\hline ROA & 0.263 & 0.793 \\
\hline Independent Sample t-test & 0.217 & 1.541 \\
\hline
\end{tabular}

\section{Research Discussions}

\subsection{The influence of Company Size towards Intellectual Capital Disclosure}

The result indicates that SIZE has a significant positive influence towards ICD. The result is consistent with some previous studies conducted by [11], [19], [12] and [13], which shows the company size has significant positive effects on the intellectual capital disclosure. But this result is in contrast to study conducted by [20]. The result of this study proves that the larger a company, the higher level of reporting conducted (including IC items). In other words, the larger LQ45 companies disclose more intellectual capital information than the smaller companies. Furthermore, larger companies are generally becoming a subject to special attention from financial analysts, so that in order to maintain their credibility, they have to be transparent to the public.

\subsection{The influence of Industry Type toward Intellectual Capital Disclosure}

The result also showed that the industry type having a significant impact on intellectual capital disclosure at the level of significance $10 \%$. In regard with the signaling theory, company that hopes to send a positive signal to its stakeholders will tend to disclose more information. This study also supports a study by Bozzolan et al. (2003) which argues that companies within a same industry have the same motive in the reporting activities, so when a company show a lower level disclosure compared to others within the same industry, it is a signal that company hiding some information.

\subsection{The differences of ICD between companies in High-Profile and Low-Profile Industries}

This study used independent-samples t-test to see the difference of level of intellectual capital disclosure between companies in high-profile and low-profile industries. Table above shows that the value is greater than the level of significance $(0.217>0.10)$. Even tough according to the results of the prior hypothesis $(\mathrm{H} 2)$ proved that high-profile companies exhibit greater disclosure than low-profile companies, however the result of independent t-test indicated that there is no statistically significant difference between high-profile and low-profile industries. This result is similar to the study by [21]. In this case, the insignificant differences of ICD between this two types of industries is probably occurs 
because each company whether in high-profile or low-profile industries are tend to provide a complete information to the stakeholders. Therefore, companies across the industries are equally eager to disclose information as complete as possible, including information related to IC items as the company's business strategy.

\subsection{The influence Profitability towards Intellectual Capital Disclosure}

The result of t-test shows that level of significance of ROA is above the significance value 0.1 ; it means that profitability has no significant influence to ICD. The result is consistent with the study by [13] and [19] which also failed to support the influence of profitability towards ICD.

The signaling theory by [8] explained that high profitability companies use their financial information to send signals to the market. Furthermore, high profitability companies may have advantage to signal their stakeholder that they are a good company by giving more information about the IC items in its annual reports. However, this study indicates that profitability does not significantly influence the level of ICD. It related with the signaling theory, companies with high profitability tend to not disclose more information related to intellectual capital because they already send a positive signal to the market regarding the financial information. Thus, any additional voluntary disclosure made by company will no longer necessary.

\subsection{The influence of Intellectual Capital toward Market Capitalization}

The result of the t-test showed that there is a high significant relationship between these two variables. The findings are similar to study by [22] and [23]. The more IC items owned by company, the higher market capitalization would be. Under the stakeholder theory, when a company has higher level of IC, the managers will let the public (stakeholders) know about how is the management performance. The stakeholders would value more regarding to the information disclosure, and thus it might decrease the misevaluation of the company's share price. Moreover, eventually company's share price would increase. As a result of the higher share prices, company's market capitalization would be also affected.

\section{Conclusion, limitation and suggestion}

The results proved that company size, industry type and market capitalization are significantly associated with the ICD, while the influence of company profitability on the level of ICD is not significant. Furthermore, it is revealed that there is no significant difference with regard to the intellectual capital disclosure practices between companies in high- and low-profile industries.

There are several limitations of the study that influenced the interpretation of the results from the study. Firstly, only three independent variables are used in the study (model 1) in order to examine the level of ICD. $\mathrm{R}^{2}$ result shows that those variables are only able to explain the model at $8.1 \%$, and $91.8 \%$ are explained by other variables which have better capabilities in explaining the ICD. The second limitation is the use of ROA. The study reveals that the ROA is not significantly influence into the level of ICD.

Based on those limitations, this study proposed some suggestion to mitigate the limitations. First, future studies could also analyses controlling factors to provide additional insights into the relationships between the IC's determinants and ICD. Even tough the role of control variables is not a primary concern in the results, but by adding some control variables hopes that the value of coefficient of determinants will increased. Second, further research could use another measurement of profitability such as ROE or NRM. Ideally, the different measurements of company profitability might offer a different statistical result.

\section{References}

1. Li, J., Pike, R., \& Haniffa, R. Intellectual capital disclosure and corporate governance structure in UK firms. Accounting and Business Research, 38(2), 137-159 (2008)

2. Drucker, P. The Future That Has Happened Already. Harvard Business Review, 75(5), 20-22 (1997)

3. Lev, B. and Zarowin, P. The boundaries of financial reporting and how to extend them. Journal of Accounting Research, 37(2), 353-83 (1999)

4. Eccles, R. and S. Mavrinac. Improving the Corporate Disclosure Process. Sloan Management Review, Summer, 36(4), 11-25 (1995)

5. IAI. The Indonesian Financial Accounting Standards (PSAK) 19

6. Barney, J. Firm Resources and Sustained Competitive Advantage. Journal of Management, 17(1), 99-120 (1991)

7. Miles, R. E., \& Snow, C. C. Organizational Strategy, Structure, and Process. New York: McGraw-Hill (1978)

8. Spence, Michael. Job Market Signaling. The Quarterly Journal of Economics, 87 (3), 355-374 (1973) 
9. Yi, A. \& Davey, H. Intellectual capital disclosure in Chinese (mainland) companies. Journal of Intellectual Capital, 11(3), 326-347 (2010)

10. Basuki, B \& Kusumawardhani, T. Intellectual Capital, Financial Profitability, and Productivity: An Exploratory Study of the Indonesian Pharmaceutical Industry. Asian Journal of Business and Accounting 5(2), 41-68 (2012)

11. Bozzolan, S., Favotto, F., \& Ricceri, F. Italian annual intellectual capital disclosure. Journal of Intellectual Capital, 4(4), 543-558 (2003)

12. Ousama, A. A., Fatima, A. and Hafiz-Majdi, A. R. Determinants of intellectual capital reporting Evidence from annual reports of Malaysian listed companies. Journal of Accounting in Emerging Economies, 2(2), 119-139 (2012)

13. Ferreira, A. L., Branco. M. C. and Moreira, J. A. Factors influencing intellectual capital disclosure by Portuguese companies. International Journal of Accounting and Financial Reporting, 2(2), 278-298 (2012)

14. Ousama, A. A. and Fatima, A. H. Factors influencing voluntary disclosure: empirical evidence from Shari'ah approved companies. Malaysian Accounting Review, 9(1), 85-103 (2010)

15. Utomo, Muhammad Muslim. Praktek Pengungkapan Sosial Pada Laporan Tahunan Perusahaan di Indonesia (Studi Perbandingan Antara Perusahaan High Profile dan Low Profile). Simposium Nasional Akuntansi IV, IAI (2000)

16. Ang, Robbert. Buku Pintar Pasar Modal Indonesia (The Intelligent Guide to Indonesian Capital Market, Mediasoft Indonesia

17. Guthrie, James and Petty, R. Intellectual Capital: Australian Annual Reporting Practices. Journal of Intellectual Capital, 1 (3), 241-251 (2000)

18. Guthrie, James and R. Petty, K. Yongvanich, F. Ricceri. Using content analysis as a research method to inquire into intellectual capital reporting. Journal of Intellectual Capital, Vol. 5 Iss: 2, pp.282 - 293 (2004)

19. Oliveira, L., L. L. Rodrigues, and R. Craig. Firm-specific determinants of intangibles reporting: Evidence from the Portuguese stock market. Journal of Human Resource Costing and Accounting, 10(1), 11-33 (2006)

20. Bukh, P. N., C. Nielsen, P. Gormsen, \& J. Mouritsen. Disclosure of information on intellectual capital in Danish IPO prospectuses. Accounting, Auditing and Accountability Journal, 18(6), 713-732 (2005)

21. Bronzetti, G, Mazzotta, R, Sicoli, G, \& Baldini, M.A. Intellectual Capital Disclosure in Sustainability Reports. Intellectual Capital Strategy Management for Knowledge-Based Organization. Hershey, PA, USA: IGI Global. 2013. pp. 195-214 (2013)

22. Abdolmohammadi, M. J. Intellectual capital disclosure and market capitalization. Journal of Intellectual Capital, 6(3), 397-416 (2005)

23. Abeysekera, I., \& Guthrie, J. An empirical investigation of annual reporting trends of intellectual capital in Sri Lanka. Critical Perspectives on Accounting, 16(3), 151-163 (2002)

24. Donaldson, T., \& Preston, L. E. The Stakeholder Theory of the Corporation: Concepts, Evidence, and Implications. The Academy of Management Review, 20(1), 65 (1995) 